Z. klin. Chem. u. klin. Biochem.

7. Jg., S. 458-460, September 1969

\title{
The volume displacement effect in quantitative analyses of red blood cell constituents
}

\author{
BY W. BörgI \\ Central Laboratory, Kantonsspital, Aarau (Switzerland) \\ (Eingegangen am 7. Juli 1969)
}

In the present communication a mathematical method is described for the measurement of the volume displacement effect involved in quantitative analyses of red blood cell solutes. Analytical data, obtained from the determination of small molecular weight constituents in red cell water, can be related to total red cell volume. This may then be used, in preference to cell water, as the reference base for the concentration of red cell constituents.

Der Enteiweißungseffekt ist abhängig von der Konzentration und dem partiellen spezifischen Volumen der in den Erythrocyten vorkommenden Proteine (Hämoglobin und andere Eiweißkörper). Er hat zur Folge, daß bei quantitativen chemischen Analysen infolge der Enteiweißung wesentlich höhere Werte erhalten werden, als in Gegenwart der Proteine. Dịe mathematische Berechnung dieses Effekts ermöglicht es, die Konzentration von im Exythrocytenwasser bestimmten Substanzen auf das Erythrocytenvolumen umzurechnen. Es wird vorgeschlagen, das Erythrocytenvolumen als Bezugsgröße für Konzentrationsangaben zu verwenden.

It has been demonstrated that deproteinization of human blood serum introduces a positive error of approximately $5 \%$ in the results obtained from chemical determination of small molecular weight constituents $(1,2)$. This phenomenon is caused by the displacement of a portion of the solvent volume by the proteins. As a result of deproteinization the volume of the protein equals zero. Hence, an increase, $\Delta \mathrm{C}$, in the concentration of a given small molecular weight solute must result. Mathematical evaluation of the volume displacement effect revealed the following equation (2):

$$
\Delta C=C_{d}\left[\frac{100}{100-\bar{V} \cdot C_{p}}-1\right]
$$

where $C_{d}$ denotes the concentration of a small molecular weight solute in untreated serum,

$C_{p}$ the concentration of protein $(g / 100 \mathrm{~m} /)$, and

$\bar{V}$ the apparent partial specific volume of protein. $\overline{\mathrm{V}}$ is defined as the increase in volume of a solution upon addition of $1 \mathrm{~g}$ of dried protein (3).

From the fromula it can be concluded that the volume displacement effect is influenced by the partial specific volume of protein and that it increases with increasing protein concentration. Thus, it introduces significant errors, when small molecular weight constituents are determined in the protein free filtrate of fluids containing large amounts of protein, i. e. of erythrocytes. With respect to the red cells, this disadvantage could be eliminated by using the untreated red cell mass rather than the haemoglobin and non-haemoglobin proteinfree filtrate. However, owing to its intense colour, precipitation of haemoglobin prior to quantitation of red cell solutes is often a prerequisite. Therefore, results of chemical analyses are usually related to the red cell water.
It is the purpose of this communication to present a system for the conversion to the total red cell volume ${ }^{1}$ ) of results obtained from determinations in red cell water.

\section{Mathematical considerations}

The volume of a solution containing protein is composed of

$$
\mathrm{V}_{\mathrm{t}}=\mathrm{V}_{\mathrm{p}}+\mathrm{V}_{\mathrm{p}} \quad(\mathrm{m} l)
$$

whereby $V_{t}$ represents the total volume of the solution, $V_{q}$ that of the solvent and non protein solutes and $V_{p}$ the volume occupied by the protein. The volume displaced by the protein in solution is defined

$$
\mathrm{V}_{\mathrm{p}}=\overline{\mathrm{V}} \times \mathrm{G} \quad(\mathrm{m} l)
$$

Here, $G$ designates the dry weight of protein. It is calculated from the formula

$$
\mathrm{G}=\frac{\mathrm{V}_{\mathrm{t}} \times C_{\mathrm{p}}}{100}
$$

$C_{p}$ denotes the protein concentration $(g / 100 \mathrm{~m})$.

It follows from [3] and [4]

$$
\mathrm{V}_{\mathrm{p}}=\frac{\mathrm{V}_{\mathrm{t}} \times \overline{\mathrm{V}} \times C_{\mathrm{p}}}{100}
$$

Equation [5] inserted in [2]

Hence,

$$
V_{t}=V_{t}+\left[\frac{V_{t} \times \bar{V} \times C_{p}}{100}\right]
$$

$$
\mathrm{V}_{\mathrm{q}}=\mathrm{V}_{\mathrm{t}} \times\left[1-\frac{\overline{\mathrm{V}} \times \mathrm{C}_{\mathrm{p}}}{100}\right]
$$

Supposing that $C_{d}(\mathrm{mg} / 100 \mathrm{ml})$ represents the amount of a given low molecular weight constituent in the total red cell mass $\left(V_{t}\right)$ and $C_{1}$ its concentration $(\mathrm{mg} / 100 \mathrm{ml}$ )

1) The term "total red cell volume" is used here to signify the unit of volume of untreated red cells. 
related to the red cell water $\left(V_{t}\right)$, then the following relationship exists

$$
\mathrm{C}_{\mathrm{d}}=\mathrm{C}_{\mathrm{l}} \times \frac{\mathrm{V}_{\mathrm{f}}}{\mathrm{V}_{\mathrm{t}}} \quad(\mathrm{mg} / 100 \mathrm{~m} /)
$$

If $\mathrm{V}_{\mathrm{t}}$ is replaced by the value obtained in [7], the concentration $C_{d}$ can be calculated, provided $C_{1}$ is known

$$
C_{d}=C_{i} \times\left[1-\frac{\bar{V} \times C_{p}}{100}\right] \quad(m g / 100 \mathrm{~m} /)
$$

The difference $(\Delta C)$ between $C_{d}$ and $C_{1}$, is equal to

$$
\Delta \mathrm{C}=\mathrm{C}_{\mathrm{l}}-\mathrm{C}_{\mathrm{d}} \quad(\mathrm{mg} / 100 \mathrm{~m} /)
$$

or, if $\mathrm{C}_{\mathrm{d}}$ is replaced by [?]

$$
\Delta \mathrm{C}=\frac{\mathrm{C}_{1} \times \overline{\mathrm{V}} \times \mathrm{C}_{\mathrm{p}}}{100} . \quad(\mathrm{mg} / 100 \mathrm{~m} /)
$$

As a rule, several protein components with different physico-chemical properties and in various concentrations are usually.present in biological fluids. Equation [9] and [11], respectively, must therefore be modified

$$
\begin{gathered}
C_{d}=C_{i}\left[1-\frac{\bar{V}_{1} \times C_{p_{1}}+\bar{V}_{2} \times C_{p_{2}} \ldots . . . \bar{V}_{n} \times C_{p n}}{100}\right] \\
\left.\Delta C=\frac{C_{1}\left(\bar{V}_{1} C_{p_{1}}+\bar{V}_{2} C_{p_{2}} \ldots . . \bar{V}_{n} C_{p n}\right)}{100} \quad \mathrm{mg} / 100 \mathrm{ml} /\right) \\
\mathrm{mg} / 100 \mathrm{ml}
\end{gathered}
$$

Application of equation [12] and [13] implies that the following three components are known:

1. $C_{1}$ : The concentration of a given constituent in red cell water can be determined experimentally by established methods. (If $C_{d}$ is known, $C_{1}$ can be calculated by formula [1].)

2. $C_{p}$ : By measuring the haemoglobin content of whole blood and multiplying this value with 100 $\frac{100}{\text { haematocrit (\%) }}$, the haemoglobin concentration per unit of red cell volume can easily be obtained. Usually, a value of $34 \mathrm{~g} / 100 \mathrm{~m} l$ erythrocytes is quoted in the literature (4). However, it varies considerably and must therefore be determined each time measurements of red cell solutes are carried out. The non-haemoglobin protein fraction of red cells contributes little to the volume displacement, since its concentration is only $0.87 \mathrm{~g}$ per $100 \mathrm{~m} l$ of cell mass (5).
3. $\bar{V}$ : The apparent partial specific volume of haemoglobin is $0.75 \mathrm{~m} / \mathrm{g}$ (6). For the non-haemoglobin protein a value of $0.75 \mathrm{~m} / \mathrm{g}$ is assumed here.

By introducing the corresponding values of haemoglobin and non-haemoglobin protein, equation [12] can be written

$$
\left.\mathrm{C}_{\mathrm{d}}=0.738 \times \mathrm{Cl}_{\mathrm{l}} \quad \mathrm{mg} / 100 \mathrm{~m} \mathrm{l}^{2}\right)
$$

The table 1 represents a collection from the literature of some of the red cell constituents of interest. Their concentrations, both related to red cell water $\left(\mathrm{C}_{i}\right)$ and to total red cells $\left(C_{d}\right)$ are listed in column 1 and 2, respectively. The values in column 3 have been derived from those in the first one, by applying formula [14].

As judged from the limited number of examples, a close agreement has been found between the experimental data of earlier investigators and the corresponding values calculated from the concentrations in red cell water by the present method.

\section{Conclusion}

It was as early as in 1927, when VAN SLYKE noted an increase of $4 \%$ in the values of total base of serum after deproteinization with trichloroacetic acid (1). In 1936, BALL and SADUSK (11) obtained similar results from sodium of blood serum. Some 20 years later, Albrink and coworkers (12) reported analogous findings with lactescent serum. These earlier observations were confirmed recently in the author's laboratory. Moreover, a mathematical formula has been derived which interrelates the results of chemical determination in untreated serum and in the protein-free filtrate thereof (2).

In the clinical chemistry laboratory, however, little attention has been paid to the volume displacement effect in blood serum caused by the proteins. On the other hand, there exists a rather large number of experimental data relating concentrations of red cell solutes to both cell water and total cell volume. In the

\begin{tabular}{|c|c|c|c|}
\hline \multirow[t]{2}{*}{ Constituents } & \multicolumn{2}{|c|}{ Concentrations, as stated in the literature } & \multirow{2}{*}{$\frac{\text { Concentrations, calculated from } C}{C_{d}}$} \\
\hline & $\mathrm{c}_{\mathrm{i}}$ & $c_{d}$ & \\
\hline & 1 & 2 & 3 \\
\hline $\begin{array}{l}\text { Glucose (7) } \\
\text { Sodium (8) } \\
\text { Potassium (8) } \\
\text { Creatinine (9) } \\
\text { Lactate (10) }\end{array}$ & $\begin{array}{l}102.6 \mathrm{mg} / 100 \mathrm{ml} \\
21.5 \pm 5.0 \mathrm{mVal} / \mathrm{l} \\
146.0 \pm 7.9 \mathrm{mVal} / \mathrm{l} \\
0.87 \pm 1.08 \mathrm{mg} / 1.00 \mathrm{ml} \\
12.1 \mathrm{mg} / 100 \mathrm{ml}\end{array}$ & $\begin{array}{l}7.3 .8 \mathrm{mg} / 100 \mathrm{ml} \\
16.3 \pm 3.6 \mathrm{mVal} / \mathrm{l} \\
104.5 \pm 6.4 \mathrm{mVal} / \mathrm{l} \\
0.52-0.65 \mathrm{mg} / 100 \mathrm{ml} \\
8.7 \mathrm{mg} / 100 \mathrm{ml}\end{array}$ & $\begin{array}{l}75.7 \mathrm{mg} / 100 \mathrm{ml} \\
15.8 \pm 3.7 \mathrm{mVal} / \mathrm{l} \\
107.7 \pm 5.8 \mathrm{mVa} / \mathrm{l} \\
0.64-0.80 \mathrm{mg} / 100 \mathrm{ml} \\
8.92 \mathrm{mg} / 100 \mathrm{~m} . \mathrm{l}\end{array}$ \\
\hline
\end{tabular}
past, conversion of data related to one or the other

2) The factor 0.738 applies only for a haemoglobin content of $34 \mathrm{~g} / 100 \mathrm{ml}$ of red cell volume and a non-haemoglobin protein content of $0.87 \mathrm{~g} / 100 \mathrm{ml}$.

Tab. 1

Concentration of some constituents in total red cells $\left(C_{d}\right)$ and in the protein-free filtrate $\left(C_{i}\right)$ thereof Column 1 and 2: Values collected from the literature; Column 3 : Values calculated from column 1

Figures in parantheses are reference numbers. 
compartment has been performed by assuming an average water content of red cells (13). In the present report, the exact volume of water displaced by the red cell proteins has been calculated. It is based on the well known fact that the volume occupied by the protein in solution can be measured by means of its partial specific volume and its concentration.
Although experimental data on red cell solutes are mostly related to red cell water, it is suggested here that the unit of total cell volume is used as the reference base for the expression of analytical results. Applying the above mathematical calculation this can readily be done, where, for any plausible reason, measurements have to be performed in the protein-free filtrate of erythrocytes.

\section{References}

1. van Slyke, D. D., A. Hiller and K. C. Bertheisen, J. biol. Chemistry 74, 659 (1927). - 2. BürGI, W., R. RICHTERICH and M. L. Mrttelholzer, Klin. Wschr. 45, 83 (1967). - 3. HaurowITz, F., The chemistry and function of proteins, 2nd edition, p. 114. Academic Press, Inc., New York (1963). - 4. Behrendi, H., Chemistry of erythrocytes, p. 7. Charles C. Thomas, Publishers, Springfield, Ill. (1957). - 5. idem, p. 7. - 6. SснмгDт, C. L. A., ed., The chemistry of the amino acids and proteins, p. 517. Charles C. Thomas, Publishers, Springfield, Ill., (1938). 7. Behrendi, H., Chemistry of erythrocytes, p. 84. Charles C. Thomas, Publishers, Springfield, Ill. (1957). - 8. idem, p. 116. 9. idem, p. 68. - 10. idem, p. 86. - 11. Batr, E. G. and J. F. SAduSK, J. biol. Chemistry 113, 661 (1936). - 12. Albrink, J. M., P. M. Hald, E. B. Man and J. P. Peters, J. Clin. Invest. 34, 1483 (1955). - 13. Behrendr, H., Chemistry of erythrocytes, p. 24. Charles C. Thomas, Publishers, Springfield; Ill., (1957).
Dr. W. Bürgi

Central Laboratory Kantonsspital 5001 Aarau

Switzerland 